\title{
How Neutrosophic Logic may Resolve Dispute on the Origin of the Universe through re-reading Gen. 1:1-2
}

\author{
Victor Christianto*1 \& Florentin Smarandache ${ }^{2}$ \\ 1Editorial Board, Jurnal Teologi Amreta. \\ ${ }^{2}$ Dept. Math. \& Sciences, Univ. of New Mexico, Gallup, USA. Email: \\ smarand@unm.edu
}

\begin{abstract}
In recent years, the Big Bang as described by the Lambda CDM-Standard Model Cosmology has become widely accepted by majority of physics and cosmology communities. But the philosophical problems remain, as Vaas pointed out: Did the universe have a beginning or does it exist forever, i.e. is it eternal at least in relation to the past? This fundamental question was a main topic in ancient philosophy of nature and the Middle Ages, and still has its revival in modern physical cosmology both in the controversy between the big bang and steady state models some decades ago and in the contemporary attempts to explain the big bang within a quantum cosmological (vacuum fluctuation) framework. In this paper we argue that Neutrosophic Logic offers a resolution to the long standing disputes between beginning and eternity of the Universe. In other words, in this respect we agree with Vaas, i.e. it can be shown: "how a conceptual and perhaps physical solution of the temporal aspect of Immanuel Kant's "first antinomy of pure reason" is possible, i.e. how our universe in some respect could have both a beginning and an eternal existence. Therefore, paradoxically, there might have been a time before time or a beginning of time in time." By the help of computational simulation, we also show how a model of early Universe with rotation can fit this new picture. Further observations are recommended.
\end{abstract}

Keywords: Big Bang, Steady state, rotating universe, fluid, singularity-free, cosmology model, early Universe, Genesis, Spirit in Creation.

${ }^{*}$ Correspondence: Victor Christianto. Email: victorchristianto@gmail.com (Formerly studying theology at STT Satyabhakti, now he is an independent researcher and lecturer in Malang Institute of Agriculture (IPM), Malang, Indonesia.) 


\section{Introduction}

In recent years, the Big Bang as described by the Lambda CDM-Standard Model Cosmology has become widely accepted by majority of physics and cosmology communities. But the philosophical problems remain, as Rudiger Vaas pointed out: Did the universe have a beginning or does it exist forever, i.e. is it eternal at least in relation to the past? This fundamental question was a main topic in ancient philosophy of nature and the Middle Ages. Philosophically it was more or less banished then by Immanuel Kant's Critique of Pure Reason. But it used to have and still has its revival in modern physical cosmology both in the controversy between the big bang and steady state models some decades ago and in the contemporary attempts to explain the big bang within a quantum cosmological framework.

Interestingly, Vaas also noted that Immanuel Kant, in his Critique of Pure Reason (1781/1787), argued that it is possible to prove both that the world has a beginning and that it is eternal (first antinomy of pure reason, A426f/B454f). As Kant believed he could overcome this "self-contradiction of reason“ („Widerspruch der Vernunft mit ihr selbst“, A740) by what he called "transcendental idealism", the question whether the cosmos exists forever or not has almost vanished in philosophical discussions. [3]

In this paper we will take a closer look at Genesis 1:2 to see whether the widely-accepted notion of creation ex-nihilo is supported by Hebrew Bible or not. It turns out that Neutrosophic Logic is in agreement with Kant and Vaas's position, it offers a resolution to the long standing disputes between beginning and eternity of the Universe. In other words, in this respect we agree with Vaas:

"how a conceptual and perhaps physical solution of the temporal aspect of Immanuel Kant's "first antinomy of pure reason" is possible, i.e. how our universe in some respect could have both a beginning and an eternal existence. Therefore, paradoxically, there might have been a time before time or a beginning of time in time."[3] 
In the subsequent chapter we will discuss how to answer this question by the lens of hermeneutics of Sherlock Holmes. This is a tool of mind which we think to be a better way compared to critical hermeneutics.

- What is Hermeneutics of Sherlock Holmes?

One article suggests:96

Holmes: "I have no data yet. It is a capital mistake to theorize before one has data. Insensibly one begins to twist facts to suit theories, instead of theories to suit facts."

Far too often students of the Bible (and cosmology folks as well) twist verses to suit interpretations instead of formulating interpretations to suit what the verses say.

Guide: Don't approach your passage assuming you know what it means. Rather, use the data in the passage - the words that are used and how they fit together - to point you toward the correct interpretation.

\section{A closer look at Genesis 1:1-2 \& implications}

One of the biggest mysteries in cosmogony and cosmology studies is perhaps: How to interpret properly Genesis chapter 1:2. Traditionally, philosophers proposed that God created the Universe out of nothingness (from reading "empty and formless" and "bara" words; this contention is called "creatio ex nihilo."). Understandably, such a model can lead to various interpretations, including the notorious "cosmic egg" (primeval atom) model as suggested by Georges Lemaitre, which then led to Big Bang model.[18-20] Subsequently, many cosmologists accept it for granted, that Big Bang stands as the most faithful and nearest theory to Biblical account of creation. But we can ask: Is that primeval atom model the true and faithful reading of Genesis 1:2?

96 https://www.str.org/blog/learning-hermeneutics-from-holmes 
Let us start our discussion by examining key biblical words of Hebrew Bible, especially Genesis 1:1-2. It can be shown that the widely accepted creatio ex nihilo is a post-biblical invention, rather than a faithful reading of the verses. To quote Ian Barbour: "Creation out of nothing is not a biblical concept."[4]

Let us consider some biblical passages:

- The literal meaning of Gen. 1:1, "bareishit bara Elohim." This very first statement of the book of Genesis literally reads: 'first' and 'beginning' are reasonable alternatives for the Hebrew noun, reishit. Also note that in Hebrew, subjects and verbs are usually ordered verb-first (unlike English in which the subject is written first). If the verb and subject of this verse are reordered according to natural English grammar we read: [1]

\{In, When\} \{first, beginning\} Elohim created...

reishit: The noun, reishit, has as its root the letters, ראש (Resh -AlephShin). Words derived from this root often carry the meaning of 'primary', 'chief', 'begin', 'first' or "first-in-line”, "head of”, and so forth. Harris's Theological Wordbook of the Old Testament (TWOT) is more specific, namely, reishit means[1]

“...first, beginning, choicest, first or best of a group. [Reishit is] a feminine noun derived from the root [Resh-Aleph-Shin], it appears fifty times in nearly all parts of the [Old Testament]. [Its] primary meaning is "first" or "beginning" of a series."

Accordingly, we can now retranslate bareishit bara Elohim as "When first created Elohim”, or as we would render in English,[1]

When Elohim first created... 
- Gen. 1:2, "And the earth had been." In English this is easily handled by the past perfect tense (also called the pluperfect or the "flashback" tense). Likewise, if haytah in v 1:2 is translated as a past perfect verb, then verses $1: 1-2$ would read,[1]

When Elohim first created the heavens and the earth, the earth had been ...

In this translation the Universe, in some form or other, was already in existence when God executed His first creative act, the creation of light.

- A re-reading of Gen. 2:7 with Hermeneutics of Sherlock Holmes97

If we read closely at Gen. 2: 7 , we see that man is made up of the dust of the ground (adamah) which is breathed by the breath of life by God (nephesh). Here we can ask, does this text really support the Cartesian dualism view?

We do not think so, because the Hebrew concept of man and life is integral. The bottom line: it is not the spirit trapped in the body (Platonic), but the body is flowing in the ocean of spirit.

- Let's look at three more texts:

a. Gen. 1: 2, "The earth is without form and void, darkness over the deep, and the Spirit of God hovering over the waters." Patterns such as Adam's creation can also be encountered in the creation story of the universe. Earth and the oceans already exist (similar to adamah), but still empty and formless. Then the Spirit of God hovered over it, in the original text "ruach" can be interpreted as a strong wind (storm). So we can imagine there is wind/hurricane, then in the storm that God said, and there was the creation of the universe. See also Amos Yong's book Spirit in

97 Check Eric McKiddie's article: https://www.thegospelcoalition.org/blogs/trevin-wax/10-tips-on-solvingmysterious-bible-passages-from-sherlock-holmes/ 
Creation [6], also Hildebrandt [15]. From a scientific point of view, it is well known in aerodynamics that turbulence can cause sound (turbulence-generated sound). And primordial sound waves are indeed observed by astronomers.

b. Ps. 107: 25, "He said, he raised up a storm that lifted up his waves." The relation between the word (sound) and the storm (turbulence) is interactive. Which one can cause other. That is, God can speak and then storms, or the Spirit of God causes a storm. Then came the voice.

c. Ezekiel. 37: 7, "Then I prophesy as I am commanded, and as soon as I prophesy, it sounds, indeed, a crackling sound, and the bones meet with one another." In Ezekiel it appears that the story of the creation of Adam is repeated, that the Spirit of God is blowing (storm), then the sound of the dead bones arises.

The conclusion of the three verses above seems to be that man is made up of adamah which is animated by the breath or Spirit of God. He is not matter, more accurately referred to as spirit in matter.

In other words, a closer reading of Hebrew Bible seems to suggest that creatio ex-nihilo is a post-biblical invention. Other scholars have suggested an alternative concept, called creatio ex-materia, but many orthodox Christian scholars have raised objection to this term, partly because the term seems to undermine God's ultimate power and control of the Universe. Besides, the notion of creatio ex-materia has been advocated by Mormon preachers.

To overcome this problem, and based on what we learned recently, allow us now to come up with a new term: creatio ex-rotatione (rotatione is a Latin word for "rotation)". As we shall see in the next chapter, it is possible to come up with a physical model of early Universe with rotation, where the raw materials have been existed for long period of time, but suddenly it burst out into creation. And it seems to fit with Kant's idea to resolve the dichotomy between finite past or eternal Universe. Furthermore, it can be shown that the 
model naturally leads to accelerated expansion, without having to invoke ad hoc assumptions like dark energy or cosmological constant.

\section{A computational model of rotation in early Universe}

Our discussion starts from the fundamental question: how can we include the rotation in early Universe model? After answering that question, we will discuss how "turbulence-generated sound" can be put into a mathematical model for the early Universe. We are aware that the notion of turbulencegenerated sound is not a new term at all especially in aerodynamics, but the term is rarely used in cosmology until now. We shall show that 3D NavierStokes will lead to non-linear acoustics models, which means that a turbulence/storm can generate sound wave.

It has been known for long time that most of the existing cosmology models have singularity problem. Cosmological singularity has been a consequence of excessive symmetry of flow, such as "Hubble's law". More realistic one is suggested, based on Newtonian cosmology model but here we include the vortical-rotational effect of the whole Universe.

In other paper, we obtained an Ermakov-type equation following Nurgaliev [8]. Then we solve it numerically using Mathematica 11. An interesting result from that simple computational simulation is shown in the following diagram:[9] 


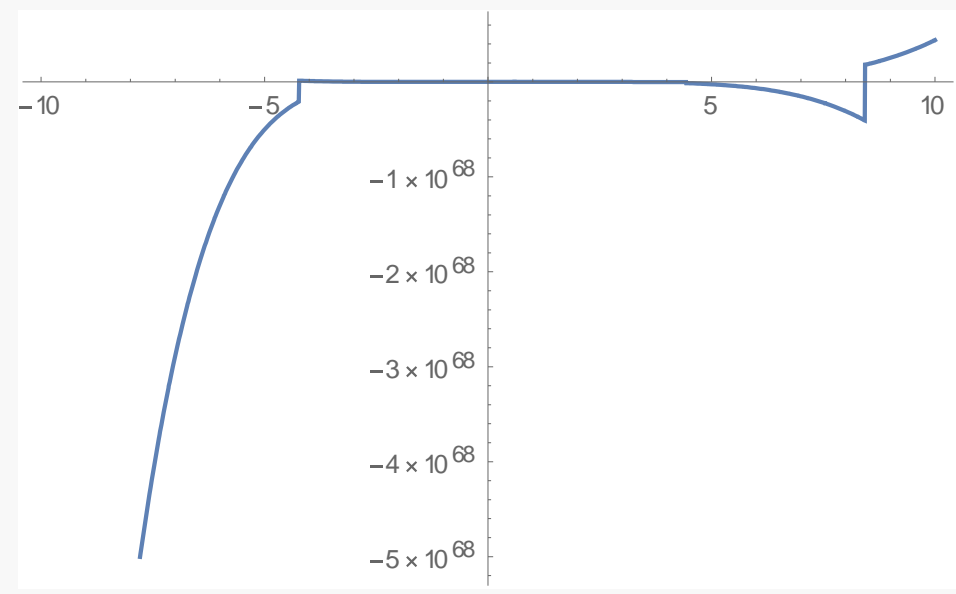

Diagram 1. Plot of Ermakov-type equation for $A=1, B=-10$ (from [9])

From the above computational experiment, we conclude that the evolution of the Universe depends on the constants involved, especially on the rotationalvortex structure of the Universe. This needs to be investigated in more detailed for sure.

One conclusion that we may derive especially from Diagram 1, is that our computational simulation suggests that it is possible to consider that the Universe has existed for long time in prolonged stagnation period, then suddenly it burst out from empty and formless (Gen. 1:2), to take its current shape with observed "late accelerated expansion."

As an implication, we may arrive at a precise model of flattening velocity of galaxies without having to invoke ad-hoc assumptions such as dark matter.

Therefore, it is perhaps noteworthy to discuss briefly a simple model of galaxies based on a postulate of turbulence vortices which govern the galaxy dynamics. The result of Vatistas's model equation can yield prediction which is close to observation, as shown in the following diagram:[14] 


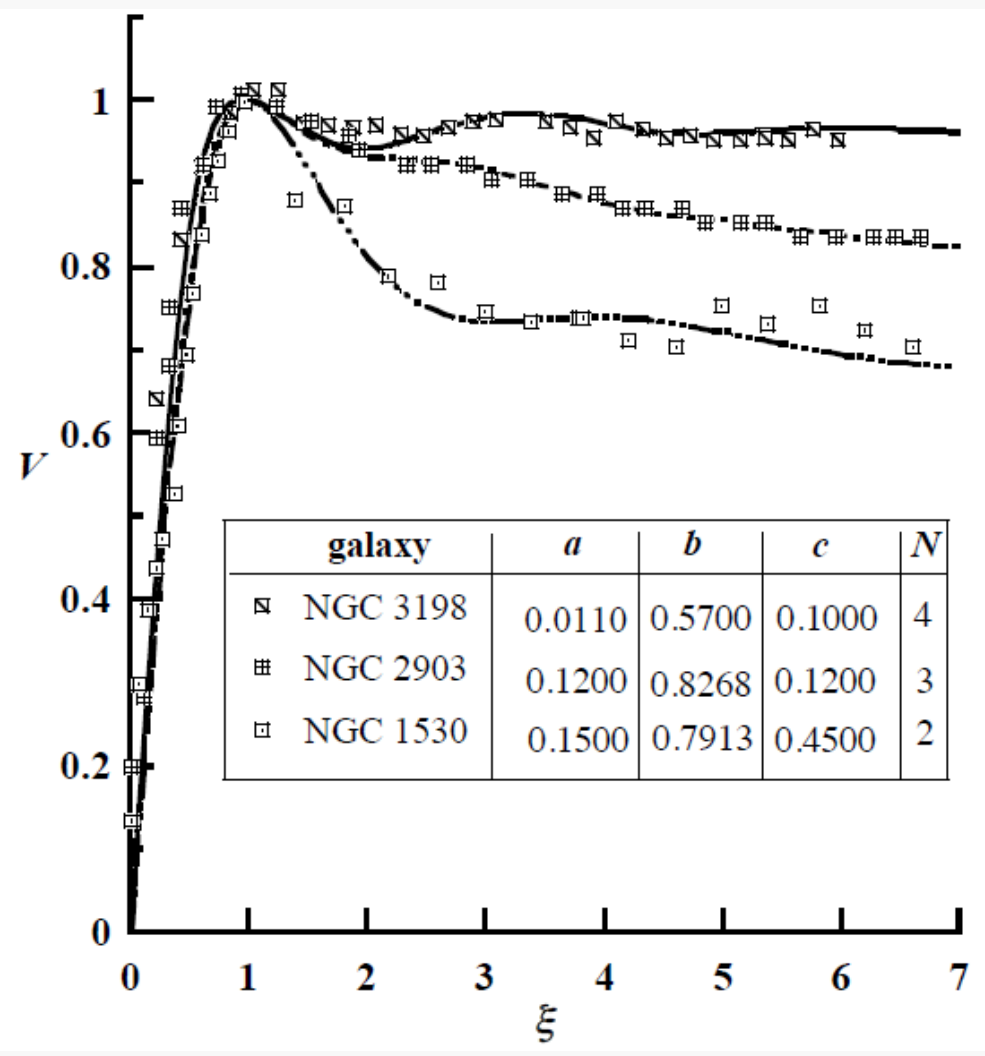

Figure 1. From Vatistas [14]

Therefore, it appears possible to model galaxies without invoking numerous ad hoc assumptions such as dark matter, once we accept the existence of turbulent interstellar medium. The Vatistas model is also governed by Navier-Stokes equations, see for instance [14].

\section{Neutrosophic Logic perspective and implications}

In the previous sections we have discussed how a closer look at Gen. 1:1-2 leads to different scenario than the widely accepted creatio ex-nihilo. This new scenario is quite in agreement with Kant's idea that it is possible that the Universe has both finite history in the past and also eternal background. We also discussed how such a mixed view can be modelled by introducing rotation in the early universe.

Now there is an immediate question: Is this new look at the origin of Universe justifiable logically, or is it merely a compromised solution? 
So, in this chapter we will review Neutrosophic Logic, a new theory developed in recent decades by one of these authors (FS).

Vern Poythress argues that sometimes we need a modification of basics of philosophy of mathematics, in order to re-define and redeem mathematics; see [21]. In this context, allow us to argue in favor of Neutrosophic logic as one basic postutale, in lieu of the Aristotle logic which creates many problems in real world.

In Neutrosophy, we can connect an idea with its opposite idea and with its neutral idea and get common parts, i.e. $\langle\mathrm{A}\rangle / \backslash<$ nonA $>=$ nonempty set. The common part of the uncommon things! It is true/real... paradox. From neutrosophy, all started: neutrosophic logic, neutrosophic set, neutrosophic probability, neutrosophic statistics, neutrosophic measure, neutrosophic physics, neutrosophic algebraic structures etc.

It is true in restricted case, i.e. the Hegelian dialectics considers only the dynamics of opposites $(<A>$ and $<$ antiA $>)$, but in our everyday life, not only the opposites interact, but the neutrals <neutA $>$ between them too. For example: you fight with a man (so you both are the opposites). But neutral people around both of you (especially the police) interfere to reconcile both of you. Neutrosophy considers the dynamics of opposites and their neutrals.

So, neutrosophy means that: $<\mathrm{A}>$, <antiA $>$ (the opposite of $<\mathrm{A}>$ ), and $<$ neutA $>$ (the neutrals between $<$ A $>$ and $<$ antiA $>$ ) interact among themselves. A neutrosophic set is characterized by a truth-membership function ( $\mathrm{T})$, an indeterminacy-membership function (I), and a falsity-membership function $(\mathrm{F})$, where T, I, F are subsets of the unit interval $[0,1]$.

As particular cases we have: single-valued neutrosophic set when T, I, F are crisp numbers in $[0,1]\}$, and interval-valued neutrosophic set $\{$ when T, I, F are intervals included in $[0,1]\}$.

Neutrosophic Set is a powerful structure in expressing indeterminate, vague, incomplete and inconsistent information. See also [22]-[24].

To summarize, Neutrosophic Logic study the dynamics of neutralities. And from this viewpoint, we can understand that it is indeed a real possibility 
that the Universe has both initial start (creation) but with eternal background. This is exactly the picture we got after our closer look at Gen. $1: 1-2$ as discussed in the above section.

In other words, our proposed term of "creatio ex-rotatione" has sufficient logical background.

\section{Advantages of "creatio ex-rotatione" concept}

In the preceding section, we have discussed on how our proposed term of "creatio ex-rotatione" has sufficient logical background.

Now, allow us to discuss some advantages of the proposed "creatio exrotatione" cosmology view over the Lemaitre's primeval atom hypothesis (which is the basis of Standard Model Cosmology).

a. Explain excess of handedness in galaxies As reported by Longo et al, there is an excess of left-handedness in spiral galaxies. According to Longo, the simplest explanation of such left-handedness is that there is net angular momentum of the Universe. This seems to suggest that our hypothesis of creatio exrotatione is closer to the truth with respect to origin of the Universe. [2]

b. Avoid inflationary scheme.

It is known that inflationary models were proposed by Alan Guth et al. (see [25][26]), in order to explain certain difficulties in the Big Bang scenario. But some cosmology experts such as Hollands \& Wald have raised some difficulties with inflationary model, as follows:

"We argue that the explanations provided by inflation for the homogeneity, isotropy, and flatness of our universe are not satisfactory, and that a proper explanation of these features will require a much deeper understanding of the initial state of our universe."[27] 
In our diagram plot above, it is clear that an early rotation model can explain why the Universe can burst out into creation in a very short period, without invoking ad hoc hypothesis such as inflation model.

c. Explain late accelerated expansion.

As far as we know, one of the earliest models which gave prediction of accelerated expanding Universe is Carmeli's Cosmological General Relativity.[29]

But it has been shown by Green \& Wald that for the large scale structures of the Universe, Newtonian model can give similar results compared to general relativity picture.[28]

Furthermore, it seems that there is no quite clear argument why we should accept Carmeli's use of 5D metric model (space-time-velocity metric).

In the meantime, in our rotating Universe model, we do not invoke ad hoc dimension into the metric.

d. Explain inhomogeneity, breeding galaxies etc.

Astronomers have known for long time, that the Universe is not homogeneous and isotropic as in the usual model. It contains of inhomogeneity, irregularity, clumpiness, voids, filaments etc, which indicate complex structures. Such inhomogeneous structures may be better modelled in terms of turbulence model such as Navier-Stokes equations, see also our early papers [11][12].

Furthermore, observations clearly suggest that matter ejected continuously in galaxy centers, which view is difficult to reconcile with Big Bang scenario of galaxy creation.

\section{Conclusions}

In this paper we argue that Neutrosophic Logic offers a resolution to the long standing disputes between beginning and eternity of the Universe. In other words, in this respect we agree with Vaas, i.e. it can be shown: "how a 
conceptual and perhaps physical solution of the temporal aspect of Immanuel Kant's "first antinomy of pure reason" is possible, i.e. how our universe in some respect could have both a beginning and an eternal existence. Therefore, paradoxically, there might have been a time before time or a beginning of time in time."

We argue that a close re-reading of Genesis 1:2 will lead us to another viable story compared from Lemaitre's primeval atom model of early Universe, albeit this alternative has not been developed rigorously as LCDM theories.

By the help of computational simulation, we also show how a model of early Universe with rotation can fit this new picture. And one conclusion that we may derive especially from Diagram 1, is that it is possible to consider that the Universe has existed for long time in prolonged stagnation period, then suddenly it burst out from empty and formless (Gen. 1:2), to take its current shape with accelerated expansion. Such a possibility has never been considered before in cosmology literatures.

It is our hope that our exploration will lead to more realistic nonlinear cosmology theories which are better in terms of observations, and also more faithful to Biblical account of creation.

Acknowledgment: The first author (VC) would like to express his gratitude to Dr. Joas Adiprasetya, Dr. Yonky Karman, and Dr. Wonsuk Ma for discussions on early creation of the Universe. We also thank to a number of professors in physics, including Prof. Bambang Hidayat, Prof. Liek Wilardjo and Prof. Thee Houw Liong. May God be with you.

Document history: version 1.0: 10 March 2018, pk. 20:22

VC \& FS 


\section{References}

[1] http://learn-biblical-hebrew.com/hebrew-scripture/beginning-genesis-11-24a/appendix/creatio-ex-materiagenesis-11-2/

[2] Michael J. Longo. 2007. Evidence for a Preferred Handedness of Spiral Galaxies. arXiv: astroph/0707.3793; [2a] M.J. Longo. Does the Universe Have a Handedness? arXiv: 0812.3437; [2b] M.J. Longo. Physics Letters B 10.1016.

[3] Rudiger Vaas. 2004. Time before Time: Classifications of universes in contemporary cosmology, and how to avoid the antinomy of the beginning and eternity of the world. arXiv: 0408111.

[4] Paul Copan. 1996. Is creation ex-nihilo a post-biblical invention? An examination of Gerhard May's proposal. TRINJ $17 \mathrm{NS}$

[5] Helge Kragh. 2017. Cosmology and the Origin of the Universe: Historical and Conceptual Perspectives. arXiv: 1706.00726

[6] Amos Yong. 2011. The Spirit of Creation. Cambridge: Wm. B. Eerdmans Publ. Co.

[7] Gerhard F. Hasel. The polemic nature of the Genesis Cosmology. The Evangelical Quarterly.

[8] Ildus S. Nurgaliev. 2012. E pur si muove! arXiv: 1210.4091. [8a] see also Singularities are averted by vortices. 13th Gravitational Conference - International Conference on Gravitation, Cosmology and Astrophysics. June 23-28, 2008. Peoples Friendship University of Russia (PFUR), Moscow, Russia. Abstracts. Published by PFUR, ISBN 978-5-209-03274-8, pp. 117-118; [8b] Also in Gravitation and Cosmology vol. 16 no. 4 (2010) pp. 313-315.

[9] Victor Christianto \& Florentin Smarandache \& Yunita Umniyati. 2017. Solving Numerically Ermakov-type Equation for Newtonian Cosmology Model with Vortex. Prespacetime Journal, Oct. 2017. www.prespacetime.com

[10] V. Christianto. 2014. An Outline of Cosmology Based on Interpretation of the Johannine Prologue, The Bulletin of Society for Mathematical Services and Standards, Vol. 11, pp. 4-12, 2014. url: https://www.scipress.com/BSMaSS.11.4

[11] V. Christianto. 2015. Four Possible Applications of a Navier-Stokes Cosmology. Prespacetime Journal Vol. 6 No. 11, url: http://www.prespacetime.com

[12] V. Christianto. 2015. A Possible Route to Navier-Stokes Cosmology on Cantor Sets. Prespacetime Journal Vol. 6 No. 8. url: http://www.prespacetime.com

[13] V. Christianto. 2017. A Theo-Cymatic Reading of Prolegomena of St. John's Gospel. Scientific GOD Journal, Vol. 8 no. 4, url: http://www.scigod.com/index.php/sgj/article/view/544/595

[14] Georgios Vatistas. 2012. The presence of interstellar turbulence could explain the velocity flattening in galaxies. arXiv: 1012.1384

[15] Wilf Hildebrandt. 1995. An Old Testament Theology of the Spirit of God. Peabody: Hendrickson Publisher, Inc.

[16] Fedor V. Shugaev, Dmitri Y. Cherkasov and Oxana A. Solenaya. 2015. Acoustic radiation by 3D vortex rings in air. Aerospace 2015, 2, 627-636; doi:10.3390/aerospace2040627

[17] Anna Rozanova-Pierrat. 2016. Approximation of a compressible Navier-Stokes system by non-linear acoustical models. arXiv: 1601.0558

[18] J-P. Luminet. 2013. Editorial note to: Georges Lemaître, A homogeneous universe of constant mass and increasing radius accounting for the radial velocity of extra-galactic nebulae. Gen. Rel. Grav. (2013) 45. url: http://www.physics.umd.edu/grt/taj/675e/Luminet_on_Lemaitre_history.pdf

[19] J-P. Luminet. 2015. Lemaitre's Big Bang. Frontiers of Fundamental Physics 14. url: https://arxiv.org/ftp/arxiv/papers/1503/1503.08304.pdf 
[20] Simon Mitton. 2016. Georges Lemaitre: Life, science, and legacy. url: https://arxiv.org/ftp/arxiv/papers/1612/1612.03003.pdf

[21] Vern Poythress. 2015. Redeeming Mathematics: A God-centered approach. Wheaton: Crossway.

[22] Florentin Smarandache. 1998. Neutrosophy. Neutrosophic Probability, Set, and Logic, ProQuest Information \& Learning, Ann Arbor, Michigan, USA, 105 p.; http://fs.gallup.unm.edu/eBookneutrosophics6.pdf (edition online).

[23] Florentin Smarandache. 2013. n-Valued Refined Neutrosophic Logic and Its Applications in Physics, Progress in Physics, 143-146, Vol. 4;

http://fs.gallup.unm.edu/n-ValuedNeutrosophicLogic-PiP.pdf

[24] F. Smarandache. 2016. Neutrosophic Overset, Neutrosophic Underset, and Neutrosophic Offset. Similarly for Neutrosophic Over-/Under-/Off-Logic, Probability, and Statistics, 168 p., Pons Editions, Brussels, Belgium, on Cornell University's website:

https://arxiv.org/ftp/arxiv/papers/1607/1607.00234.pdf

and in France at the international scientific database:

https://hal.archives-ouvertes.fr/hal-01340830

[25] Alan H. Guth. 2004. Inflation. Carnegie Observatories Astrophysics Series, Vol. 2: Measuring and Modeling the Universe. W. L. Freedman (Cambridge: Cambridge Univ. Press)

[26] Alan H. Guth. 2001. Eternal Inflation. MIT-CTP-3007, arXiv: astro-ph/0101507

[27] S. Hollands \& R.M. Wald. 2002. An alternative to inflation. arXiv: gr-qc/0205058

[28] Stephen Green and R.M. Wald. 2011. Newtonian and Relativistic Cosmologies. arXiv: 1111.2997

[29] Moshe Carmeli. 1999. Aspects of Cosmological Relativity. http://cds.cern.ch/record/394536/files/9907080.pdf; [29a] see also M. Carmeli. Cosmological Relativity: The Special and General Theories for the Structure of the Universe. World Scientific Publ. url: https://www.worldscientific.com/worldscibooks/10.1142/6275

\section{Editor's note:}

In order that the readers can find a more balanced perspective, here we include the comments from reviewer on this paper:

"Artikel ini memandang Kejadian 1:1-2 sebagai sebuah scientific statements. Padahal ini tidak dapat dipandang demikian. Jika 1:1-2 dipandang sebagai scientific statements maka the rest of the account should be treated the same. Jika itu dilakukan maka akan menimbulkan kesulitan, seperti masalah hari misalkan. Apakah hari akan dipandang sebagai 24 jam atau jaman atau apa? Beberapa pandangan yang ada itu juga menonjolkan argumen scientific mereka masing-masing. Lebih luas, kejadian 1:1-2 adalah bagian dari unit yang lebih besar yaitu kejadian 1-11 atau primeval history. Maka seharusnya unit yang lebih besar inipun harus dipandang sebagai collection of scientific statements. Jika demikian semakin banyak 
kesulitan akan muncul, menjelaskan terangkatnya henokh, masalah diterimanya persembahan Habel dan ditolaknya persembahan Kain, bagaimana kain bisa mengerti jika persembahannya ditolak, dll Pemisahan be dengan reshit dan menerjemahkannya menjadi ketika Allah menciptakan adalah pemisahan yang tidak tepat. Bereshit selalu muncul dalam construct state yang berarti in the beginning. The fact that ruach elohim can refer to great ancient mighty wind observed by astronomer is not a direct prove that creatio ex nihilo is wrong.

Ps. 107: 25, $\rightarrow$ Psalm is a poem which use hiperbolic expression, thus the structure of the word in this verse can not be used as a refference of how is the order of the event naturally.

Ezekiel. 37: 7 pada hakikatnya adalah bahasa figuratif yang tentunya symbol simbol di dalamnya tidak dapat digunakan secara sejajar untuk sesuatu yang sifatnya scientific.

bagaimana bisa mengatakan bahwa creatio ex nihilo adalah ide post biblical invention dan kemudian malah mengusulkan creatio ex rotatione yang disebut cocok dengan idenya Kant. Bukankah ini dapat disebut lebih "post biblical" dari yang ditolaknya tadi.

Spirit sebagai material in the spirit sangat tidak tepat dengan pandangan Ibrani tentang spirit. Spirit is seen as perpanjangan tangan dari Allah. Finally rotational model completelly asing bagi hebrew people, but sovereignity of God is not.

After all, this is a very good effort to explain from the scientific point of view of creation.

\section{Further comments:}

Karena tulisan ini lebih ke arah science, justru perbedaan yang ada yang saya berikan di atas akan mengajar pembaca untuk melihat pergumulan antara science dan faith. Jadi rekomendasi saya adalah publish as submitted. 